\title{
Angiotensin Receptor Antagonists to Prevent Sudden Death in Heart Failure: Does the Dose Matter?
}

\author{
Pietro Francia, ${ }^{1}$ Francesca Palano, ${ }^{1}$ Giuliano Tocci, ${ }^{1}$ Carmen Adduci, ${ }^{1}$ Agnese Ricotta, \\ Lorenzo Semprini, ${ }^{1}$ Massimo Caprinozzi, ${ }^{1}$ Cristina Balla, ${ }^{1}$ and Massimo Volpe ${ }^{1,2}$ \\ ${ }^{1}$ Cardiology, Department of Clinical and Molecular Medicine, Sant'Andrea Hospital, Sapienza University, \\ Via di Grottarossa 1035-39, 00189 Rome, Italy \\ ${ }^{2}$ I.R.C.C.S. Neuromed, Pozzilli, Italy
}

Correspondence should be addressed to Massimo Volpe; massimo.volpe@uniromal.it

Received 4 October 2013; Accepted 1 December 2013; Published 6 February 2014

Academic Editors: W. Bloch, Y. Levy, P. S. Rahko, and J. S. Steinberg

Copyright (C) 2014 Pietro Francia et al. This is an open access article distributed under the Creative Commons Attribution License, which permits unrestricted use, distribution, and reproduction in any medium, provided the original work is properly cited.

International guidelines recommend ICD implantation in patients with severe left ventricular dysfunction of any origin only after careful optimization of medical therapy. Indeed, major randomized clinical trials suggest that suboptimal use of fundamental drugs, such as ACE inhibitors (ACE-i) and beta-blockers, may affect ICD shock-free survival, sudden cardiac death (SCD), and overall mortality. While solid evidence in favour of pharmacological therapy based on ACE-i with or without beta-blockers is available, data on SCD in HF patients treated with angiotensin receptor blockers (ARBs) are limited. The present paper systematically analyses the impact of ARBs on SCD in HF and reviews the contributory role of the renin-angiotensin system (RAS) to the establishment of arrhythmic substrates. The following hypothesis is supported: (1) the RAS is a critical component of the electrical remodelling of the failing myocardium, (2) RAS blockade reduces the risk of SCD, and (3) ARBs represent a powerful tool to improve overall survival and possibly reduce the risk of SCD provided that high doses are employed to achieve optimal $\mathrm{AT}_{1}$-receptor blockade.

\section{Introduction}

Heart failure (HF) affects 15 million people in Europe, with a prevalence of $2-3 \%$ in the general population and $10-20 \%$ in 70 - to 80 -year-old subjects. It represents the common ending of different cardiovascular diseases and is characterized by high short-term mortality in advanced stages (up to $50 \%$ at 1 year for NYHA class IV patients) [1-4].

Death in HF occurs either from circulatory failure due to progressive left ventricular (LV) dysfunction or sudden cardiac death (SCD). This latter accounts for approximately half of all HF deaths, the underlying mechanism being sudden onset of ventricular tachycardia (VT) or ventricular fibrillation (VF). Despite decades of research for the evaluation of hundred compounds, there are no antiarrhythmic drugs that definitely prevent SCD in HF patients on already optimized therapy with $\beta$-blockers and ACE inhibitors [5]. In contrast, the implantable cardioverter-defibrillator (ICD) prevents SCD and improves survival in both primary and secondary prevention patients treated with optimal medical therapy, including beta-blockers and either ACE inhibitors or angiotensin receptor blockers (ARBs) [6-8].

Based on data from multiple randomized primary prevention trials, current guidelines recommend ICD implantation in patients with symptomatic and severe LV dysfunction of any origin on already optimized medical therapy [9]. However, the concept of optimal drug treatment in ICD trials has been questioned [10]. Indeed, most primary and secondary prevention studies show an increased risk of death or appropriate ICD interventions associated with an imbalanced use of antiarrhythmic drugs or $\beta$-blockers and ACE-inhibitors among the study arms [10]. Findings from these clinical trials suggested that suboptimal use of fundamental drugs, such as ACE inhibitors and beta-blockers, may impact on eventfree survival, SCD, and overall mortality. With the exception of the SCD-HeFT [8], DINAMIT [11], DEFINITE [12], and MADIT II [7] trials, only 8 to $50 \%$ of patients enrolled in major primary prevention studies were on $\beta$-blockers, and less than $70 \%$ of patients were treated with ACE-i. While solid 
evidence in favour of pharmacological therapy based on ACE-i with or without beta-blockers is available, data on SCD in HF patients treated with ARBs are limited.

The present paper systematically analyses the impact of ARBs on SCD in HF and reviews the contributory role of the renin-angiotensin system (RAS) to the establishment of proarrhythmic substrates.

\section{ARBs and Sudden Death in Clinical Trials}

The ELITE study [13] was originally designed to compare the effects of losartan (50 $\mathrm{mg}$ /day) and captopril (50 $\mathrm{mg}$ three times daily) on renal function in HF patients. Although renal outcomes were similar in the two groups, the results of a secondary endpoint analysis showed a $45 \%$ reduction in total mortality in HF patients randomized to losartan compared to placebo, mainly driven by a $36 \%$ decrease in SCD [13]. As the superior effects of losartan were based on a small number of events that were not the primary endpoint, a larger randomised trial, the ELITE II [14] (Table 1), was specifically designed to evaluate mortality. In this trial, losartan $50 \mathrm{mg}$ once daily did not prove superior efficacy as compared to captopril $50 \mathrm{mg}$ three times daily and showed a trend towards higher incidence of sudden death or resuscitated cardiac arrest (HR: 1.25; 95\% CI: 0.98-1.60; $P=0.08$ ) [14].

The Val-HeFT trial [15] (Table 1) was a randomized, placebo-controlled, double-blind, and parallel-group trial, evaluating the long-term effects of the addition of valsartan to standard therapy in more than 5.000 patients with HF. Eligible patients included in this trial had to have been receiving for at least two weeks a fixed-dose drug regimen that could include ACE inhibitors, diuretics, digoxin, and beta-blockers. The primary outcomes were mortality and the combined endpoint of mortality and morbidity, defined as the incidence of cardiac arrest with resuscitation, hospitalization for heart failure, or receipt of intravenous inotropic or vasodilator therapy. Although overall mortality was similar in the two groups, valsartan reduced the risk of first hospitalisation for HF by $34.4 \%(P=0.0007)$ as compared to placebo. In addition, resuscitation of cardiac arrest was improved with valsartan, without achieving statistically significance $(0.6$ versus $1.0 \%, P=\mathrm{ns})$. However, at the time of randomization, about $93 \%$ of patients were on ACE inhibitors in both treatment arms, not allowing to assess the isolated benefits of ARBs.

In the OPTIMAAL trial [16] (Table 1), comparing captopril and losartan in high-risk patients after acute myocardial infarction, all-cause mortality was nonstatistically different in the two study arms and showed a trend towards higher incidence of death (RR 1.13; 95\% CI 0.99-1.28; $P=0.07$ ) and SCD (RR 1.19; 95\% CI 0.98-1.43; $P=0.07$ ) in the losartan as compared to captopril group.

The VALIANT study [17] (Table 1) randomized 14.703 patients with myocardial infarction complicated by HF, left ventricular dysfunction or both to valsartan $160 \mathrm{mg}$ twice daily, captopril $50 \mathrm{mg}$ three times daily, or captopril $50 \mathrm{mg}$ three times daily plus valsartan $80 \mathrm{mg}$ twice daily. The primary endpoint of the study was death from any cause. The results showed noninferiority of valsartan compared with that of captopril. In a post hoc analysis of the risk and time course of SD in the VALIANT study population [18], 1067 patients $(7 \%)$ experienced SD $(n=903)$ or resuscitated cardiac arrest $(n=164)$ in a median of 180 days after MI. The risk was the highest in the first 30 days after MI (1.4\% per month) and was decreased ( $0.14 \%$ per month) after 2 years. Unfortunately, this analysis did not address which of the drug regimens was more effective in preventing SD or resuscitated cardiac arrest.

The CHARM programme [19], including three trials, reported that ARBs provide incremental benefit over background therapy with ACE-i in HF [20] and improve major endpoints when used as a replacement therapy in patients intolerant to ACE-i [21]. Indeed, in subjects who are intolerant to ACE-i, the CHARM Alternative trial [21], demonstrated that candesartan reduces cardiovascular death and hospital admissions for congestive $\mathrm{HF}$ as compared to the placebo group. Moreover, a post hoc analysis evaluating cause-specific mortality [22] (Table 1) revealed that the major reduction in cardiovascular mortality observed in the candesartan arm was ascribed to fewer SCD and HF deaths, accounting for $35 \%$ and $26 \%$ of all deaths, respectively.

The low doses of ARBs used in the former trials may at least in part explain the higher mortality as compared to that observed in the CHARM overall programme. This hypothesis is also supported by the recent findings of a registry-based cohort study [23] assessing whether losartan was associated with increased all-cause mortality in HF patients as compared with candesartan. Overall, drug therapy with losartan was not associated with higher mortality. However, mortality was higher when losartan was administered at low doses [23].

All these studies suggest that undertitration of ARBs may be associated with a poor outcome. Less information is given if beta-blocker cotreatment influences the dose response of ARBs. Of note, patients enrolled in all the above-mentioned trials were on optimized medical treatment including betablockers, the only drugs that proved to be effective in reducing sudden cardiac death, cardiovascular death and all cause mortality in HF [24]. In VALIANT, OPTIMAAL and COMPANION trials, the percentage of patients on betablockers was indeed $70 \%$ on average. To date, there are no published studies addressing the specific question whether beta-blockers modify the risk of sudden death in patients treated with suboptimal doses of ARBs.

\section{ARBs in ICD Recipients with HF}

Among clinical trials that demonstrated a significant survival benefit of the ICD $[6,8,25]$, only SCD-HeFT reported on the use of ARBs (15\% of patients at study entry) [8]. However, there are no available follow-up data of this study subgroup.

In a post hoc analysis of the COMPANION trial (Table 1), Saxon et al. [26] reported that both ACE-i and ARBs lowered the risk of appropriate ICD therapy. However, they did not report whether patients on ARBs were also on an ACE-i or whether ARBs were used at high or low doses. Providing this information is crucial when interpreting results.

In a population of ICD recipients with left ventricular ejection fraction $<35 \%$ and no prior documented ventricular 
TABLE 1: Clinical studies assessing the impact of ARBs on SCD, RCA,or appropriate ICD intervention.

\begin{tabular}{|c|c|c|c|c|c|}
\hline Study & $\begin{array}{l}\text { Aim of the study or } \\
\text { primary endpoint }\end{array}$ & SCD & $\begin{array}{l}\text { Mean daily dose of } \\
\text { ARB }\end{array}$ & \multicolumn{2}{|c|}{ Results } \\
\hline ELITE II [14] & $\begin{array}{l}\text { Losartan versus } \\
\text { captopril to improve } \\
\text { survival in patients } \\
\text { with NYHA II-IV } \\
\text { and FE } \leq 40 \% \\
\end{array}$ & $\begin{array}{l}\text { Secondary } \\
\text { endpoint }\end{array}$ & $\begin{array}{l}\text { Losartan } 50 \mathrm{mg} \text { versus } \\
\text { captopril } 50 \mathrm{mg} \text { t.i.d. }\end{array}$ & $\begin{array}{l}\text { Losartan not superior } \\
\text { for mortality } \\
\text { Higher incidence of } \\
\text { SCD or RCA with } \\
\text { losartan }\end{array}$ & $\begin{array}{l}\text { HR } 1.25 \\
\text { CI } 95 \%(0.98-1.60) \\
P=0.08\end{array}$ \\
\hline Val-HeFT [15] & $\begin{array}{l}\text { Valsartan for } \\
\text { mortality and } \\
\text { morbidity in NYHA } \\
\text { II-IV }\end{array}$ & & $\begin{array}{l}\text { Valsartan } 160 \mathrm{mg} \\
\text { b.i.d. versus placebo }\end{array}$ & $\begin{array}{l}\text { Total mortality } \\
\text { similar in the two } \\
\text { groups } \\
\text { RCA improved with } \\
\text { valsartan }\end{array}$ & $\begin{array}{l}\text { RR } 1.02 \\
\text { CI } 97.5 \%(0.88-1.18) \\
P=0.80 \\
0.6 \% \text { versus } 1.0 \%\end{array}$ \\
\hline OPTIMAAL [16] & $\begin{array}{l}\text { Losartan versus } \\
\text { captopril to decrease } \\
\text { all-cause mortality } \\
\text { after acute MI }\end{array}$ & $\begin{array}{l}\text { Secondary } \\
\text { endpoint }\end{array}$ & $\begin{array}{l}\text { Losartan } 50 \mathrm{mg} \text { versus } \\
\text { captopril } 50 \mathrm{mg} \text { t.i.d. }\end{array}$ & $\begin{array}{l}\text { Trend in favor of } \\
\text { captopril (death from } \\
\text { any cause) } \\
\text { Higher incidence of } \\
\text { SCD or RCA with } \\
\text { losartan }\end{array}$ & $\begin{array}{l}\text { RR } 1.13 \\
\text { CI 95\% (0.99-1.28) } \\
P=0.07 \\
\text { RR 1.19; CI 95\% } \\
0 \cdot 98-1 \cdot 43 ; P=0.07\end{array}$ \\
\hline VALIANT [17] & $\begin{array}{l}\text { Valsartan versus } \\
\text { captopril in patients } \\
\text { with MI associated } \\
\text { with } \mathrm{HF} \text { and/or LVD }\end{array}$ & & $\begin{array}{l}\text { Valsartan } 160 \mathrm{mg} \\
\text { b.i.d. versus captopril } \\
50 \text { mg t.i.d. } \\
\text { versus valsartan + } \\
\text { captopril }\end{array}$ & $\begin{array}{l}\text { Valsartan noninferior } \\
\text { to captopril for total } \\
\text { mortality }\end{array}$ & $\begin{array}{l}\text { HR } 1.00 \\
\text { CI } 97.5 \%(0.90-1.1) \\
P=0.98\end{array}$ \\
\hline $\begin{array}{l}\text { CHARM } \\
\text { post hoc analysis [22] }\end{array}$ & $\begin{array}{l}\text { Candesartan for } \\
\text { cause-specific } \\
\text { mortality in HF } \\
\text { patients }\end{array}$ & - & $\begin{array}{l}\text { Candesartan titrated } \\
\text { to } 32 \mathrm{mg} \text { versus } \\
\text { placebo }\end{array}$ & $\begin{array}{l}\text { Reduction of SCD } \\
\text { with candesartan }\end{array}$ & $\begin{array}{l}\text { HR } 0.85 \\
\text { CI } 95 \%(0.73-0.99) \\
P=0.036\end{array}$ \\
\hline HEAAL [32] & $\begin{array}{l}\text { Losartan } 50 \mathrm{mg} \text { versus } \\
150 \mathrm{mg} \text { for death or } \\
\text { admission for HF }\end{array}$ & - & $\begin{array}{l}\text { Losartan } 50 \mathrm{mg} \text { versus } \\
\text { losartan } 150 \mathrm{mg}\end{array}$ & $\begin{array}{l}\text { Reduction of death or } \\
\text { admission for HF } \\
\text { with } 150 \mathrm{mg} \\
\text { No effects on } \\
\text { mortality }\end{array}$ & $\begin{array}{l}\text { HR } 0.90,95 \% \text { CI } \\
0.82-0.99 ; P=0.02 \\
\text { HR } 0.94,95 \% \text { CI } \\
0.84-1.04 ; P=0.24\end{array}$ \\
\hline $\begin{array}{l}\text { COMPANION } \\
\text { post-hoc analysis [26] }\end{array}$ & $\begin{array}{l}\text { Predictors of SCD or } \\
\text { ICD intervention in } \\
\text { patients receiving } \\
\text { CRT }\end{array}$ & - & Unknown & $\begin{array}{l}\text { Both } \mathrm{ACE}-\mathrm{i} \text { and } \mathrm{ARBs} \\
\text { reduced the risk of } \\
\text { appropriate shocks }\end{array}$ & $\begin{array}{l}\text { ACE-i: HR } 0.44 \\
\text { CI } 95 \%(0.26-0.75) \\
P<0.01 \\
\text { ARBs: HR } 0.53 \\
\text { CI 95\% }(0.28-0.996) \\
P 0.05\end{array}$ \\
\hline Obeyesekere et al. [27] & $\begin{array}{l}\text { Predictors of } \\
\text { appropriate ICD } \\
\text { interventions in a } \\
\text { primary prevention } \\
\text { population }\end{array}$ & - & Unknown & $\begin{array}{l}\text { Absence of } \\
\text { ACE-i/ARBs predicts } \\
\text { appropriate ICD } \\
\text { intervention }\end{array}$ & $\begin{array}{l}\text { OR } 0.06 \\
\text { CI } 95 \%(0.01-0.37) \\
P<0.003\end{array}$ \\
\hline Francia et al. [28] & $\begin{array}{l}\text { Predictors of } \\
\text { appropriate ICD } \\
\text { interventions in } \\
\text { a primary prevention } \\
\text { population }\end{array}$ & - & $\begin{array}{l}\text { Losartan } 50 \mathrm{mg}(75 \% \\
\text { of patients) }\end{array}$ & $\begin{array}{l}\text { Low-dose ARBs } \\
\text { associated with } \\
\text { higher risk of ICD } \\
\text { intervention }\end{array}$ & $\begin{array}{l}\text { HR } 2.9 \\
\text { CI } 95 \%(1.1-7) \\
P=0.02\end{array}$ \\
\hline
\end{tabular}

ARBs: angiotensin receptor antagonists; SCD: sudden cardiac death; RCA: resuscitated cardiac arrest; CRT: cardiac resynchronization therapy.

arrhythmias, Obeyesekere et al. [27] (Table 1) reported that appropriate device therapy occurred more frequently in patients without background therapy with ACE-i or ARBs. We recently conducted a prospective study to identify determinants of appropriate ICD interventions in a cohort of patients with HF implanted with a primary prevention ICD
(Table 1). Interestingly, we found that patients treated with low-dose ARBs (75\% assuming losartan at a mean dose of $51 \mathrm{mg} /$ day) had a 2.4-fold increased risk of appropriate ICD intervention. This emphasizes that ARBs uptitration plays a key role in the protection against ventricular arrhythmias and possibly SCD [28]. 


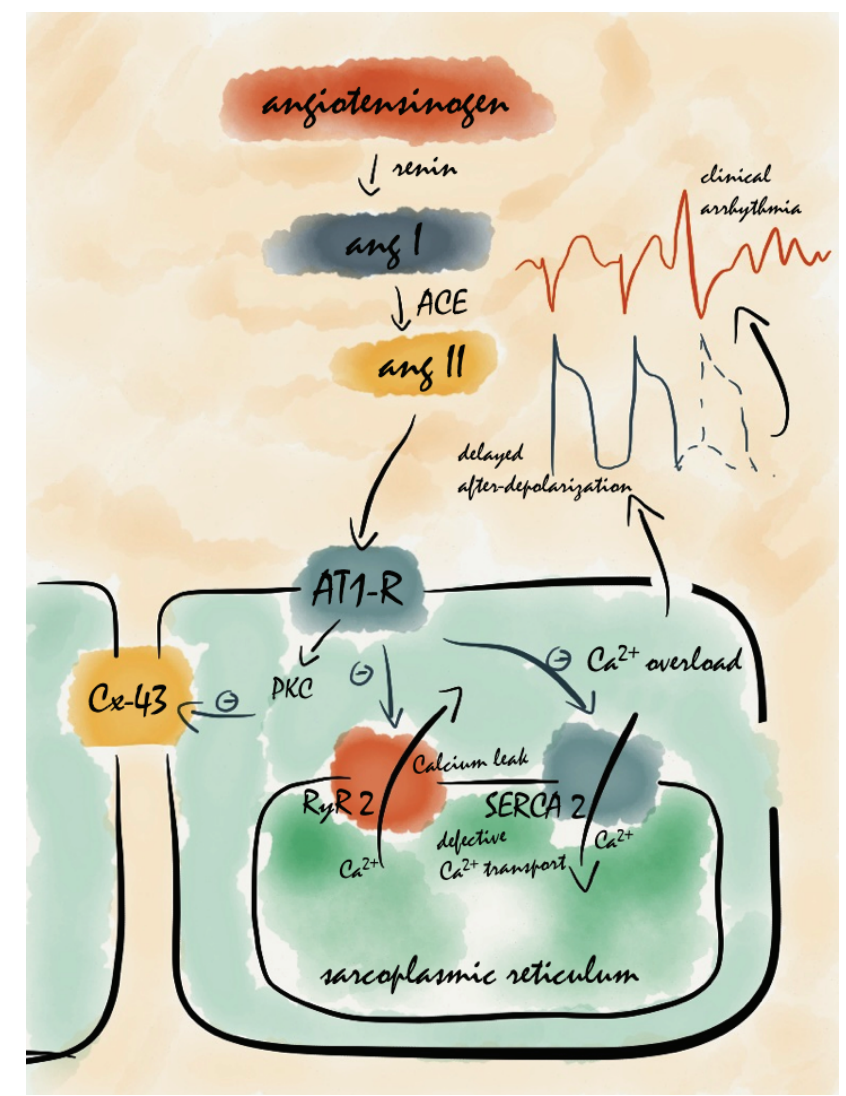

FIGURE 1: Molecular mechanisms that link $\mathrm{AT}_{1}$ receptor and arrhythmia susceptibility are summarized on this picture. The $\mathrm{AT}_{1}$ receptor downregulates connexin 43 via protein kinase $\mathrm{C}$ (PKC), thus favouring fragmentation and electrical reentry of the stimuli that can lead to tachyarrhythmias. Angiotensin II also affects $\mathrm{Ca}^{2+}$ homeostasis via the $\mathrm{AT}_{1}$ receptor by downregulating sarcoplasmic reticulum (SR) $\mathrm{Ca}^{2+}$-ATPase pump (SERCA 2a) and altering ryanodine receptor 2 (RyR2) function. Downregulation of SERCA2a through the AT ${ }_{1}$ receptor determines defective SR $\mathrm{Ca}^{2+}$ reuptake and promotes protein kinase A (PKA) phosphorylation of RyR2, thus leading to diastolic $\mathrm{Ca}^{2+}$ leak from the SR. The resultant cytoplasmic $\mathrm{Ca}^{2+}$ overload can trigger spontaneous delayed afterdepolarizations and ventricular arrhythmias.

\section{Magnitude of RAS Blockade}

Based on the pharmacodynamic profile of ARBs, dosages required to achieve a complete blockade of the $\mathrm{AT}_{1}$-subtype receptor (e.g., lack of vasoconstrictor response to a challenge with angiotensin II) are higher than those commonly used in clinical practice. In their experience on normotensive healthy volunteers, Mazzolai et al. [29] found that oral administration of losartan $50 \mathrm{mg}$ provides only 35 to $45 \%$ blockade of $\mathrm{AT}_{1}$ receptors. This is consistent with findings from Maillard et al. [30], who reported on the effects of losartan, valsartan, and candesartan dosing on $\mathrm{AT}_{1}$ receptor blockade. In their study, oral administration of losartan $50 \mathrm{mg}$ induced only $50 \%$ $\mathrm{AT}_{1}$ receptor blockade, which was comparable to valsartan $80 \mathrm{mg}$. Blockade of $67 \%$ of $\mathrm{AT}_{1}$ receptors required valsartan $160 \mathrm{mg}$.

Notably, main trials in HF patients allowed ARB doses that are considerably higher than those traditionally employed in clinical practice. In the Val-HeFT [15] the target daily dose of valsartan was $320 \mathrm{mg}$, and the CHARM studies [19-21, 31] allowed candesartan at a target dose of $32 \mathrm{mg} /$ day. With specific regard to losartan, the HEAAL study [32]
(Table 1) assessed whether $150 \mathrm{mg} /$ day was superior to $50 \mathrm{mg} /$ day in reducing morbidity and mortality in a cohort of 3.846 symptomatic HF patients. After a median follow-up of 4.7 years, losartan $150 \mathrm{mg} /$ day significantly reduced hospital admissions for HF (HR 0.87; 95\% CI: 0.76-0.98; $P=0.025$ ) and showed a nonsignificant trend towards reduction in mortality (HR 0.94; 95\% CI: $0.84-1.04 ; P=0.24$ ) as compared with losartan $50 \mathrm{mg} /$ day. Among components of primary endpoint, SCD and progressive HF represented the most common causes of death (37\% and $24 \%$ of deaths, resp.).

\section{Electrical Remodelling and RAS Blockade: Focus on Mechanisms}

Myocardial remodelling of the failing heart involves progressive loss of tissue due to necrosis and fibrosis, leading to inhomogeneous electrical conduction and offering the ideal milieu for triggering and propagation of ventricular arrhythmias. Local RAS expression contributes substantially to myocardial structural changes that favour cardiac arrhythmias [33]. Angiotensin II exerts its arrhythmogenic effects via 
multiple mechanisms that may involve or not the $\mathrm{AT}_{1}$ receptor. Among $\mathrm{AT}_{1}$ receptor-mediated mechanisms, angiotensin II decreases gap junction conductance via protein kinase C activation [34], shortens the refractory period by reducing the action potential duration [35], and modifies calcium conductance in cardiomyocytes [36]. Indeed, angiotensin II affects intracellular calcium homeostasis by targeting sarcoplasmic reticulum $\mathrm{Ca}^{2+}$-ATPase pump and ryanodine receptor [37, 38], thus promoting sarcoplasmic reticulum (SR) $\mathrm{Ca}^{2+}$ leak and defective $\mathrm{SR} \mathrm{Ca}^{2+}$ reuptake during diastole. The resultant cytoplasmic $\mathrm{Ca}^{2+}$ overload can trigger delayed afterdepolarizations and ventricular arrhythmias [39, 40] (Figure 1). As $\mathrm{AT}_{1}$ receptors are widely expressed in the cardiac conduction system, angiotensin II may promote electrical instability also via enhanced spontaneous activity trough activation of the $\mathrm{AT}_{1}$ receptor in the sinoatrial/atrioventricular node and Purkinje fibres. Indeed, in isolated cardiac Purkinje fibres, angiotensin II increases the height and duration of the plateau phase of the action potential and promotes an inward shift in membrane current [41].

The increase in sympathetic activity via catecholamine release is among the main non- $\mathrm{AT}_{1}$ receptor-mediated arrhythmogenic effects of angiotensin II. Indeed, angiotensin II favours sympathetic neurotransmission in cardiac nerve terminals via inhibition of norepinephrine reuptake of neuronal cells [42] and suppression of vagal discharge of carotid sinus baroreceptor fibres [43]. Additional secondary arrhythmogenic mechanisms may involve direct tissue damage. As reported [44], infusion of angiotensin II in rabbits produces focal areas of myocardial necrosis probably due to the high sensitivity of coronary arteries to the vasoconstrictor effect of angiotensin II. Accordingly, necrosis/scarring of the conduction system may result, and ultimately lead to cardiac arrhythmias.

Dysfunctioning gap junctions are also likely to be involved in arrhythmogenis driven by angiotensin II. In an animal model of myocardial infarction, Kieken et al. [45] showed that angiotensin II upregulates c-Src tyrosine kinase, leading to downregulation of connexin 43 ( $\mathrm{Cx} 43)$, a major component of gap junction architecture. Loss of $\mathrm{Cx} 43$ causes fragmentation and slowdown of electrical stimuli, thereby favouring electrical reentry and tachyarrhythmias. Recently, Sovari and colleagues [46] demonstrated that, in a transgenic mouse model overexpressing cardiac angiotensin-converting enzyme (ACE 8/8 mice), c-Src tyrosine kinase inhibition prevents $\mathrm{Cx} 43$ loss, thus reducing susceptibility to cardiac arrhythmia. Interestingly, RAS blockade with losartan and captopril in ACE 8/8 mice induced a 2.4- and 2.3-fold increase in total cardiac $\mathrm{Cx} 43$ expression [47].

It is noteworthy that the contributory role of $\mathrm{AT}_{2}$ receptors in establishing life-threatening arrhythmic substrates or providing antiarrhythmic effects is poorly addressed at present. In animal models, $\mathrm{AT}_{1}$ receptor blockade with losartan significantly increases $\mathrm{AT}_{2}$ receptor mRNA [48]. Moreover, when experimental myocardial infarction is induced, the $\mathrm{AT}_{2}$ receptor agonist compound 21 (C21) reduces scar size by diminishing Fas-ligand and caspase- 3 expression in the peri-infarct zone, indicating an antiapoptotic effect [49].
It seems reasonable that reducing scar size may also entail antiarrhythmic effects.

Both ACE-i and ARBs counteract the proarrhythmic effects of angiotensin II. Indeed, ACE-i prevent the conversion of angiotensin I to angiotensin II, while ARBs directly block $\mathrm{AT}_{1}$ receptors. As compared to ACE-i, $\mathrm{ARBs}$ have the advantage to inhibit the production of angiotensin II via ACE-independent pathways, providing a long-lasting effect that overwhelms possible loss of efficacy of ACE-i after prolonged use. Furthermore, ACE-i may increase bradykinin levels, which in turn trigger norepinephrine release leading to higher susceptibility to cardiac arrhythmias. Conversely, ARBs do not hydrolize ACE, thus preventing bradykinin increase.

\section{Conclusions}

The RAS contributes substantially to myocardial electrical remodelling of the failing heart, favouring ventricular arrhythmias. In experimental settings, RAS blockade through ACE-i and ARBs $[39,47,50]$ displays antiarrhythmic properties that are both dependent on and beyond $\mathrm{AT}_{1}$ receptor pathways. In the clinical arena, drug treatment with ARBs represents a powerful tool to reduce the risk of cardiac arrhythmias, provided that full drug doses are employed. Indeed, randomized controlled trials showed that high doses of ARBs (valsartan 160-320 mg and candesartan 16-32 mg) are effective in improving survival in $\mathrm{HF}$ and may be therefore warranted also to reduce the risk of SD. On the contrary, using ARBs in this setting at suboptimal doses provides less than optimal receptor blockade, which turns to be clinically inadequate in severely diseased patients. In this view, the efficacy of high-dose ARBs in protecting HF patients from life-threatening arrhythmias should be prospectively assessed.

\section{Conflict of Interests}

There are no sources of financial support or potential conflict of interests to acknowledge.

\section{References}

[1] A. Mosterd, A. W. Hoes, M. C. de Bruyne et al., "Prevalence of heart failure and left ventricular dysfunction in the general population. The Rotterdam Study," European Heart Journal, vol. 20, no. 6, pp. 447-455, 1999.

[2] A. Mosterd and A. W. Hoes, "Clinical epidemiology of heart failure," Heart, vol. 93, no. 9, pp. 1137-1146, 2007.

[3] D. M. Lloyd-Jones, M. G. Larson, E. P. Leip et al., "Lifetime risk for developing congestive heart failure: the Framingham Heart Study," Circulation, vol. 106, no. 24, pp. 3068-3072, 2002.

[4] J. G. F. Cleland, I. Gemmell, A. Khand, and A. Boddy, "Is the prognosis of heart failure improving?" European Journal of Heart Failure, vol. 1, no. 3, pp. 229-241, 1999.

[5] I. Squire, "Neurohormonal intervention to reduce sudden cardiac death in heart failure: what is the optimal pharmacologic strategy?" Heart Failure Reviews, vol. 9, no. 4, pp. 337-345, 2004. 
[6] A. J. Moss, W. J. Hall, D. S. Cannom et al., "Improved survival with an implanted defibrillator in patients with coronary disease at high risk for ventricular arrhythmia," The New England Journal of Medicine, vol. 335, no. 26, pp. 1933-1940, 1996.

[7] A. J. Moss, W. Zareba, W. J. Hall et al., "Prophylactic implantation of a defibrillator in patients with myocardial infarction and reduced ejection fraction," The New England Journal of Medicine, vol. 346, no. 12, pp. 877-883, 2002.

[8] G. H. Bardy, K. L. Lee, D. B. Mark et al., "Amiodarone or an implantable cardioverter-defibrillator for congestive heart failure," The New England Journal of Medicine, vol. 352, no. 3, pp. 225-237, 2005.

[9] A. E. Epstein, J. P. DiMarco, K. A. Ellenbogen et al., "ACC/ AHA/HRS 2008 Guidelines for Device-Based Therapy of Cardiac Rhythm Abnormalities: a report of the American College of Cardiology/American Heart Association Task Force on Practice Guidelines (Writing Committee to Revise the ACC/AHA/NASPE 2002 Guideline Update for Implantation of Cardiac Pacemakers and Antiarrhythmia Devices): developed in collaboration with the American Association for Thoracic Surgery and Society of Thoracic Surgeons," Journal of the American College of Cardiology, vol. 51, pp. e1-e62, 2008.

[10] R. Tung, P. Zimetbaum, and M. E. Josephson, "A critical appraisal of implantable cardioverter-defibrillator therapy for the prevention of sudden cardiac death," Journal of the American College of Cardiology, vol. 52, no. 14, pp. 1111-1121, 2008.

[11] S. H. Hohnloser, K. H. Kuck, P. Dorian et al., "Prophylactic use of an implantable cardioverter-defibrillator after acute myocardial infarction," The New England Journal of Medicine, vol. 351, no. 24, pp. 2481-2488, 2004.

[12] A. Kadish, A. Dyer, J. P. Daubert et al., "Prophylactic defibrillator implantation in patients with nonischemic dilated cardiomyopathy," The New England Journal of Medicine, vol. 350, no. 21, pp. 2151-2158, 2004.

[13] B. Pitt, R. Segal, F. A. Martinez et al., "Randomised trial of losartan versus captopril in patients over 65 with heart failure (Evaluation of Losartan in the Elderly Study, ELITE)," The Lancet, vol. 349, no. 9054, pp. 747-752, 1997.

[14] B. Pitt, P. A. Poole-Wilson, R. Segal et al., "Effect of losartan compared with captopril on mortality in patients with symptomatic heart failure: randomised trial-the Losartan Heart Failure Survival Study ELITE II," The Lancet, vol. 355, no. 9215, pp. 1582-1587, 2000.

[15] J. N. Cohn and G. Tognoni, "A randomized trial of the angiotensin-receptor blocker valsartan in chronic heart failure," The New England Journal of Medicine, vol. 345, no. 23, pp. 1667$1675,2001$.

[16] K. Dickstein and J. Kjekshus, "Effects of losartan and captopril on mortality and morbidity in high-risk patients after acute myocardial infarction: the OPTIMAAL randomised trial. Optimal Trial in Myocardial Infarction with Angiotensin II Antagonist Losartan," The Lancet, vol. 360, no. 9335, pp. 752760, 2002.

[17] M. A. Pfeffer, J. J. V. McMurray, E. J. Velazquez et al., "Valsartan, captopril, or both in myocardial infarction complicated by heart failure, left ventricular dysfunction, or both," The New England Journal of Medicine, vol. 349, no. 20, pp. 1893-1906, 2003.

[18] S. D. Solomon, S. Zelenkofske, J. J. V. McMurray et al., "Sudden death in patients with myocardial infarction and left ventricular dysfunction, heart failure, or both," The New England Journal of Medicine, vol. 352, no. 25, pp. 2581-2588, 2005.
[19] M. A. Pfeffer, K. Swedberg, C. B. Granger et al., "Effects of candesartan on mortality and morbidity in patients with chronic heart failure: the CHARM-overall programme," The Lancet, vol. 362, no. 9386, pp. 759-766, 2003.

[20] J. J. V. McMurray, J. Östergren, K. Swedberg et al., "Effects of candesartan in patients with chronic heart failure and reduced left-ventricular systolic function taking angiotensinconverting-enzyme inhibitors: the CHARM-added trial," The Lancet, vol. 362, no. 9386, pp. 767-771, 2003.

[21] C. B. Granger, J. J. V. McMurray, S. Yusuf et al., "Effects of candesartan in patients with chronic heart failure and reduced left-ventricular systolic function intolerant to angiotensinconverting-enzyme inhibitors: the CHARM-alternative trial," The Lancet, vol. 362, no. 9386, pp. 772-776, 2003.

[22] S. D. Solomon, D. Wang, P. Finn et al., "Effect of candesartan on cause-specific mortality in heart failure patients: the Candesartan in Heart failure Assessment of Reduction in Mortality and morbidity (CHARM) program," Circulation, vol. 110, no. 15, pp. 2180-2183, 2004.

[23] H. Svanström, B. Pasternak, and A. Hviid, "Association of treatment with losartan vs candesartan and mortality among patients with heart failure," The Journal of the American Medical Association, vol. 307, no. 14, pp. 1506-1512, 2012.

[24] M. Al-Gobari, C. El Khatib, F. Pillon, and F. Gueyffier, "Betablockers for the prevention of sudden cardiac death in heart failure patients: a meta-analysis of randomized controlled trials," BMC Cardiovascular Disorders, vol. 13, article 52, 2013.

[25] "A comparison of antiarrhythmic-drug therapy with implantable defibrillators in patients resuscitated from near-fatal ventricular arrhythmias. The Antiarrhythmics versus Implantable Defibrillators (AVID) Investigators," The New England Journal of Medicine, vol. 337, no. 22, pp. 1576-1583, 1997.

[26] L. A. Saxon, M. R. Bristow, J. Boehmer et al., "Predictors of sudden cardiac death and appropriate shock in the Comparison of Medical Therapy, Pacing, and Defibrillation in Heart Failure (COMPANION) Trial," Circulation, vol. 114, no. 25, pp. 27662772, 2006.

[27] M. N. Obeyesekere, W. Chan, D. Stub et al., "Left ventricular ejection fraction and absence of ACE inhibitor/angiotensin II receptor blocker predicts appropriate defibrillator therapy in the primary prevention population," Pacing and Clinical Electrophysiology, vol. 33, no. 6, pp. 696-704, 2010.

[28] P. Francia, C. Balla, A. Uccellini et al., "Low-dose angiotensin receptor blockers as an alternative to ACE-inhibitors increase the risk of appropriate ICD interventions in heart failure," International Journal of Cardiology, vol. 145, no. 3, pp. 522-524, 2010.

[29] L. Mazzolai, M. Maillard, J. Rossat, J. Nussberger, H. R. Brunner, and M. Burnier, "Angiotensin II receptor blockade in normotensive subjects: a direct comparison of three AT1 receptor antagonists," Hypertension, vol. 33, no. 3, pp. 850-855, 1999.

[30] M. P. Maillard, G. Würzner, J. Nussberger, C. Centeno, M. Burnier, and H. R. Brunner, "Comparative angiotensin II receptor blockade in healthy volunteers: the importance of dosing," Clinical Pharmacology and Therapeutics, vol. 71, no. 1, pp. 68-76, 2002.

[31] S. Yusuf, M. A. Pfeffer, K. Swedberg et al., "Effects of candesartan in patients with chronic heart failure and preserved leftventricular ejection fraction: the CHARM-preserved trial," The Lancet, vol. 362, no. 9386, pp. 777-781, 2003. 
[32] M. A. Konstam, J. D. Neaton, K. Dickstein et al., "Effects of highdose versus low-dose losartan on clinical outcomes in patients with heart failure (HEAAL study): a randomised, double-blind trial," The Lancet, vol. 374, no. 9704, pp. 1840-1848, 2009.

[33] S. Iravanian and S. C. Dudley Jr., "The renin-angiotensinaldosterone system (RAAS) and cardiac arrhythmias," Heart Rhythm, vol. 5, no. 6, pp. S12-S17, 2008.

[34] W. C. de Mello, "Is an intracellular renin-angiotensin system involved in control of cell communication in heart?" Journal of Cardiovascular Pharmacology, vol. 23, no. 4, pp. 640-646, 1994.

[35] W. C. de Mello and M. J. Crespo, "Cardiac refractoriness in rats is reduced by angiotensin II," Journal of Cardiovascular Pharmacology, vol. 25, no. 1, pp. 51-56, 1995.

[36] W. C. de Mello, "Renin-angiotensin system and cell communication in the failing heart," Hypertension, vol. 27, no. 6, pp. 1267$1272,1996$.

[37] S. O. Marx, S. Reiken, Y. Hisamatsu et al., "PKA phosphorylation dissociates FKBP12.6 from the calcium release channel (ryanodine receptor): defective regulation in failing hearts," Cell, vol. 101, no. 4, pp. 365-376, 2000.

[38] G. Hasenfuss, "Alterations of calcium-regulatory proteins in heart failure," Cardiovascular Research, vol. 37, pp. 279-289, 1998.

[39] T. Tokuhisa, M. Yano, M. Obayashi et al., "AT1 receptor antagonist restores cardiac ryanodine receptor function, rendering isoproterenol-induced failing heart less susceptible to $\mathrm{Ca}^{2+}$-leak induced by oxidative stress," Circulation Journal, vol. 70, no. 6, pp. 777-786, 2006.

[40] M. Flesch, F. Schiffer, O. Zolk et al., "Angiotensin receptor antagonism and angiotensin converting enzyme inhibition improve diastolic dysfunction and $\mathrm{Ca}^{2+}$-ATPase expression in the sarcoplasmic reticulum in hypertensive cardiomyopathy," Journal of Hypertension, vol. 15, no. 9, pp. 1001-1009, 1997.

[41] R. S. Kass and M. L. Blair, "Effects of angiotensin II on membrane current in cardiac Purkinje fibers," Journal of Molecular and Cellular Cardiology, vol. 13, no. 9, pp. 797-809, 1981

[42] K. U. Malik and A. Nasjletti, "Facilitation of adrenergic transmission by locally generated angiotensin II in rat mesenteric arteries," Circulation Research, vol. 38, no. 1, pp. 26-30, 1976.

[43] E. R. Lumbers, D. I. McCloskey, and E. K. Potter, "Inhibition by angiotensin II of baroreceptor-evoked activity in cardiac vagal efferent nerves in the dog," The Journal of Physiology, vol. 294, pp. 69-80, 1979.

[44] H. Gavras, A. F. Lever, J. J. Brown, R. F. Macadam, and J. I. Robertson, "Acute renal failure, tubular necrosis, and myocardial infarction induced in the rabbit by intravenous angiotensin II," The Lancet, vol. 2, no. 7714, pp. 19-22, 1971.

[45] F. Kieken, N. Mutsaers, E. Dolmatova et al., "Structural and molecular mechanisms of gap junction remodeling in epicardial border zone myocytes following myocardial infarction," Circulation Research, vol. 104, no. 9, pp. 1103-1112, 2009.

[46] A. A. Sovari, S. Iravanian, E. Dolmatova et al., "Inhibition of cSrc tyrosine kinase prevents angiotensin II-mediated connexin43 remodeling and sudden cardiac death," Journal of the American College of Cardiology, vol. 58, no. 22, pp. 2332-2339, 2011.

[47] S. Iravanian, A. A. Sovari, H. A. Lardin et al., "Inhibition of renin-angiotensin system (RAS) reduces ventricular tachycardia risk by altering connexin43," Journal of Molecular Medicine, vol. 89, no. 7, pp. 677-687, 2011.
[48] F. Cosentino, C. Savoia, P. de Paolis et al., "Angiotensin II type 2 receptors contribute to vascular responses in spontaneously hypertensive rats treated with angiotensin II type 1 receptor antagonists," American Journal of Hypertension, vol. 18, no. 4, pp. 493-499, 2005.

[49] E. Kaschina, A. Grzesiak, J. Li et al., "Angiotensin II type 2 receptor stimulation: a novel option of therapeutic interference with the renin-angiotensin system in myocardial infarction?" Circulation, vol. 118, no. 24, pp. 2523-2532, 2008.

[50] G. P. Thomas, G. R. Ferrier, and S. E. Howlett, "Losartan exerts antiarrhythmic activity independent of angiotensin II receptor blockade in simulated ventricular ischemia and reperfusion," The Journal of Pharmacology and Experimental Therapeutics, vol. 278, no. 3, pp. 1090-1097, 1996. 


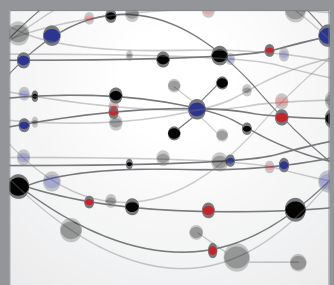

The Scientific World Journal
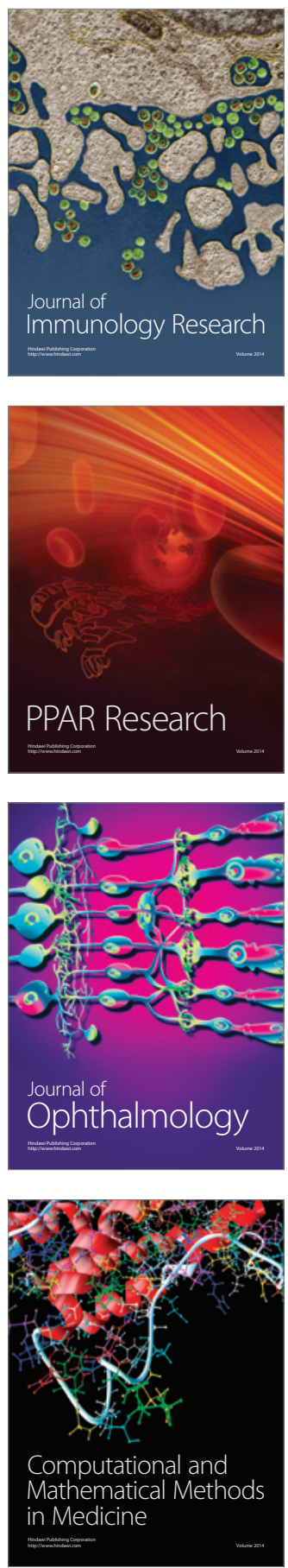

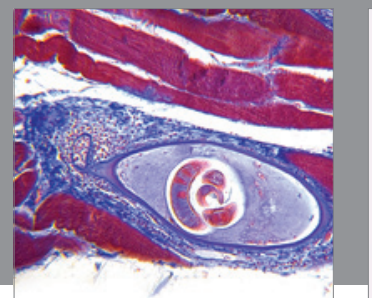

Gastroenterology

Research and Practice
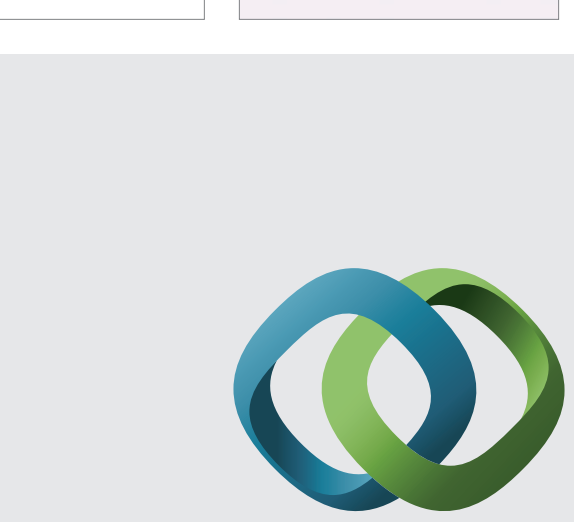

\section{Hindawi}

Submit your manuscripts at

http://www.hindawi.com
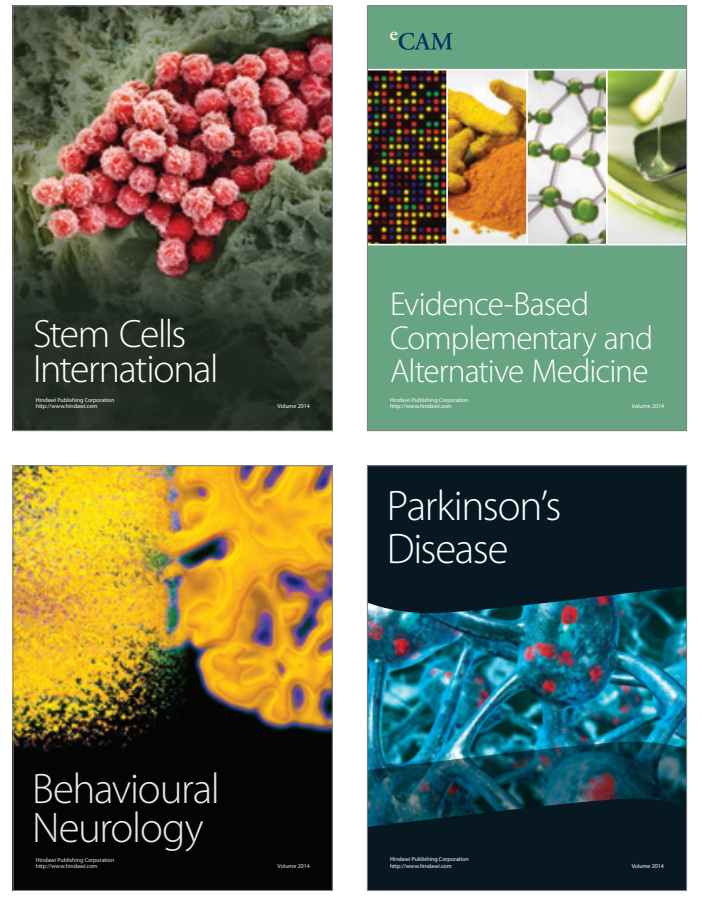
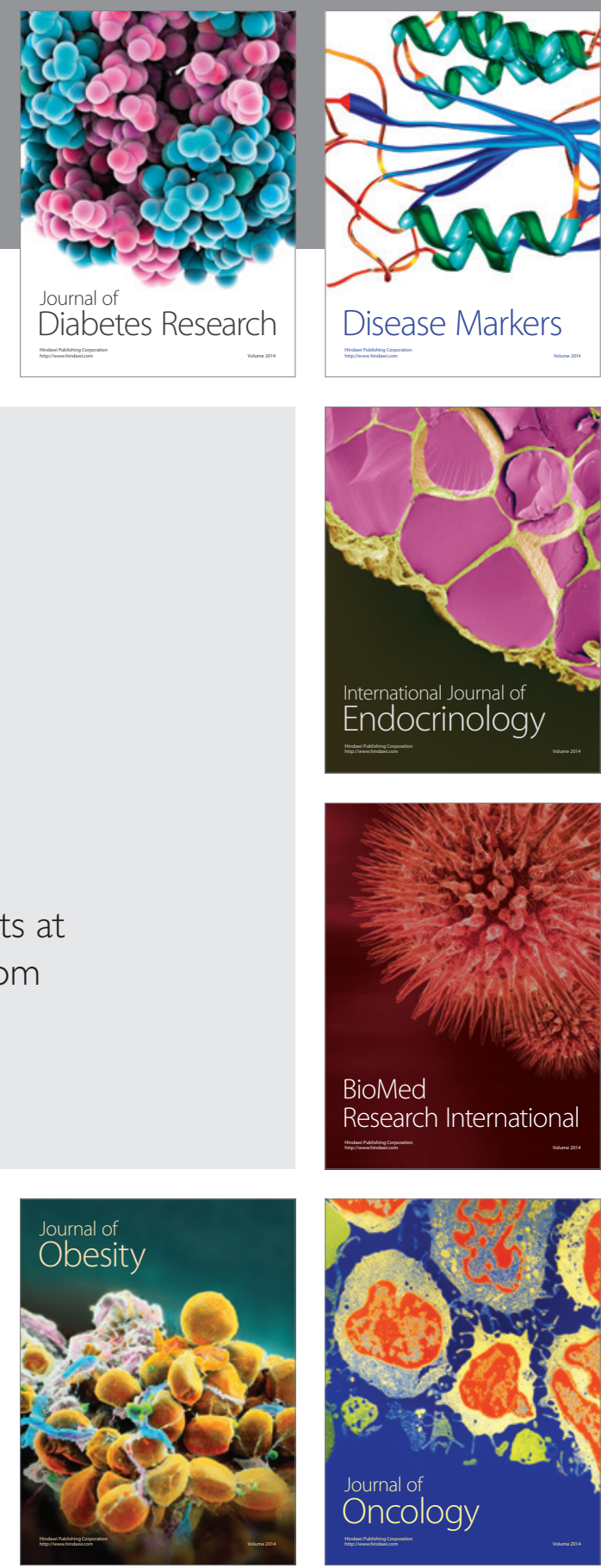

Disease Markers
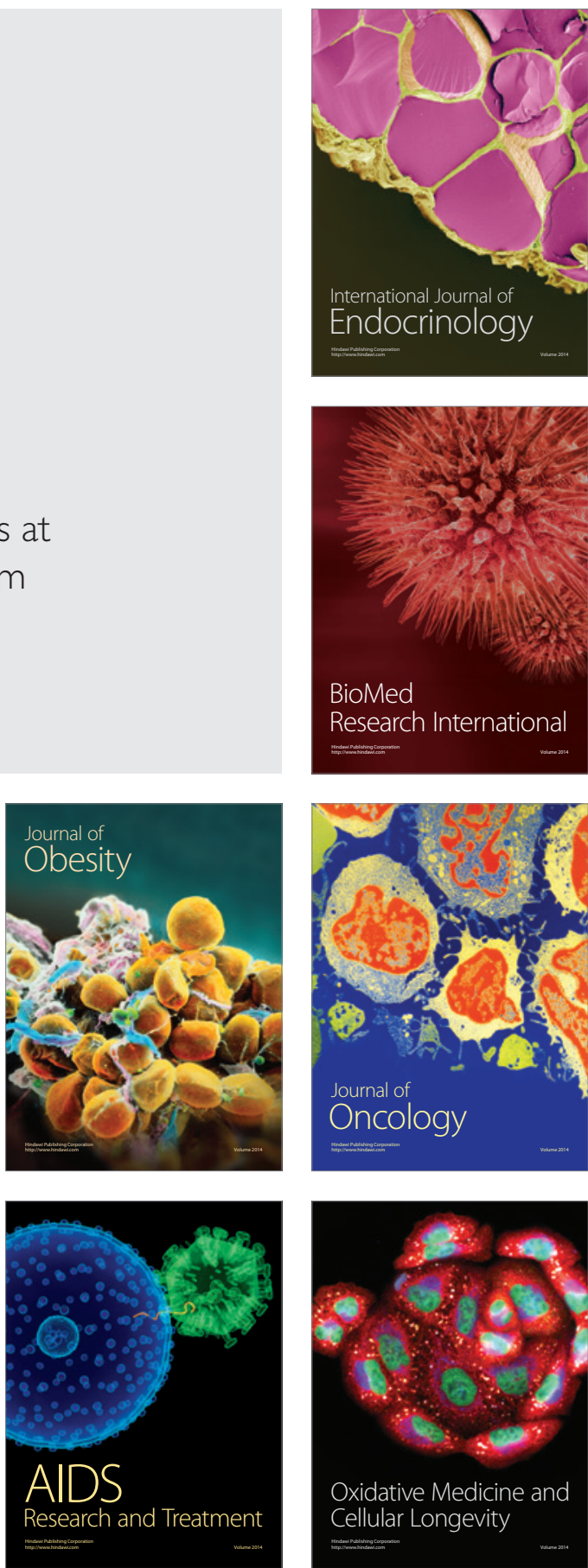